6. Brandt, J. T., Kirkwood, S., Mukopadhay, N. (2006). CYP2C19*2 polymorphism contributes to a diminished pharmacodynamic response to clopidogrel. J Am Coll Cardiol., 47, 380A.

7. Bonello, L., Armero, S., Ait Mokhtar, O., Mancini, J., Aldebert, P., Saut, N. et. al. (2010). Clopidogrel Loading Dose Adjustment According to Platelet Reactivity Monitoring in $\mathrm{Pa}-$ tients Carrying the 2C19*2Loss of Function Polymorphism. Journal of the American College of Cardiology, 56 (20), 1630 1636. doi: 10.1016/j.jacc.2010.07.004

8. Angiolillo, D. (2004). High clopidogrel loading dose during coronary stenting: effects on drug response and interindividual variability. European Heart Journal, 25 (21), 1903-1910. doi: 10.1016/j.ehj.2004.07.036
9. Collet, J.-P., Hulot, J.-S., Pena, A., Villard, E., Esteve, J.-B., Silvain, J. et. al. (2009). Cytochrome P450 2C19 polymorphism in young patients treated with clopidogrel after myocardial infarction: a cohort study. The Lancet, 373 (9660), 309-317. doi: 10.1016/s0140-6736(08)61845-0

10. Pena, A., Collet, J.-P., Hulot, J.-S., Silvain, J., Barthelemy, O., Beygui, F. et. al. (2009). Can We Override Clopidogrel Resistance? Circulation, 119 (21), 2854-2857. doi: 10.1161/circulationaha.108.857722

11. Sofi, F., Giusti, B., Marcucci, R., Gori, A. M., Abbate, R., Gensini, G. F. (2010). Cytochrome P450 2C19*2 polymorphism and cardiovascular recurrences in patients taking clopidogrel: a meta-analysis. The Pharmacogenomics Journal, 11 (3), 199-206. doi: 10.1038/tpj.2010.21

Рекомендовано до публікації член-кореспондент НАМН Украӥни, д-р мед. наук, професор Нетяженко В. 3. Дата надходження рукопису 12.05.2016

Карпенко Олена Олександрівна, кафедра пропедевтики внутрішньої медицини № 1, Національний медичний університет імені О. О. Богомольця, бул. Т. Шевченка, 13, м. Київ, Україна, 01601

E-mail: dr.elena.karpenko@gmail.com

\title{
УДК: 616-08+616.33+616.379-008.64
}

\section{ПОРІВНЯЛЬНА ЕФЕКТИВНІСТЬ МЕТОДІВ ЛІКУВАННЯ УПОВІЛЬНЕННЯ МОТОРИКИ ШЛУНКУ У ХВОРИХ НА ЦУКРОВИЙ ДІАБЕТ 1-ГО ТИПУ}

\section{() І. О. Костіцька}

Дослідження виконано для визначення ефективності сеансів акупунктури у порівнянні із прокінетиком у 46 хворих на діабетичний гастропарез. Протягом трьох місяиів основній групі (n=23) обстежених шомісячно проведено по 10 сеансів акупунктури, а групі порівняння $(n=23)$ використано 150 мг/добу ітоприду. Встановлено, щуо більи ефективним методом симптоматичної терапії слід вважати акупунктуру Ключові слова: уповільнення моторно-евакуаторної функиії илунку, иукровий діабет 1-го типу, діабетичний гастропарез, акупунктура, прокінетик, ітоприд

Deceleration of the gastric motor-evacuative function (M-EF) in patients with diabetes mellitus (DM) must be considered as an initial manifestation of gastroparesis that worsens the life quality of persons of able-bodied age and favors the labile course of the main disease. For today the questions of individualized approach to the use of symptomatic therapy are not finally solved and the treatment algorithm of correction of diabetic gastroparesis (GP) symptoms is not elaborated.

Aim of research - to compare the effectiveness of acupuncture sessions with preparation of symptomatic therapy that has prokinetic properties in complex treatment of $D G$.

Materials and methods: there were examined 66 patients with DM type 1, stratified in: the first group (n=23) patients, who underwent 30 sessions of acupuncture during three months according to the set instruction of points, in addition to the treatment complex, and the second group $(n=23)$ - three-month course of prokinetis itopride was added in day dose $150,0 \mathrm{mg}$, while patients of the control group $(n=20)$ received the standard treatment complex without preparations of symptomatic therapy for normalization of gastric M-EF. All examined in dynamics underwent determination of the severity degree of DG clinical course using three-minute questioning of patients «Gastroparesis Cardinal Symptom Index» (GCSI), and also 13C-octane respiratory test (13C-ORT), assessment of carbohydrate metabolism - by parameters of glycemic control (prandial and postprandial glycemia, glycated hemoglobin).

Results. In 69,7\% of patients with DM type 1 the manifestations of symptoms of gastric motility deceleration were diagnosed and proved by the conclusion of 13C-ORT. In 21,7\% (10 persons) of patients of the first group was revealed deceleration of time of half-evacuation of the gastric content into duodenum of the light degree and in $28,3 \%$ (13 patients) - of the middle severity, whereas in examined of the second group bradigastria of the light degree is present in y 26,1\% (12 patients), of the middle degree - in 23,9\% (11 patients). According to the results of additional observations the direct moderate correlation was revealed between the sum of points of GSCI questioning data and $13 C$-ORT results $(r=0,45, p<0,05)$, and also the strong direct connection $(r=0,76 ; p<0,05)$ between the state of compensation of carbohydrate metabolism (HbAlC, \%) and degree of deceleration of gastric motility by indices of 13C-ORT. The change data testify to the pathogenetically grounded connections between the state of carbohydrate metabolism compensation and gastric functional properties. 
Conclusions. There was established the reliably better dynamics of carbohydrate metabolism indices after threemonth treatment course in patients of the first group: glycated hemoglobin decreased by $(\Delta(-26,28) \%)$, and correspondingly the levels of prandial $(\Delta(-10,75) \%)$ and postprandial $(\Delta(-23,30) \%)$ glycemias and improvement $(\Delta(-14,63) \%)$ of gastric $M-E F$ was observed, whereas at using prokinetic itopride $150 \mathrm{mg} /$ day during three months this effect is less reliably expressed: glycated hemoglobin decreased by $\Delta(-21,34) \%$, glycemia on an empty stomach by $\Delta(-16,85) \%$, postprandial glycemia by $\Delta(-13,36) \%$, and gastric motility dynamics is less expressed $(\Delta(-6,49) \%)$. So, acupuncture must be considered as the more effective treatment method at deceleration of gastric motility in patients with diabetes mellitus type 1

Keywords: deceleration of gastric motor-evacuation function, diabetes mellitus type 1, diabetic gastroparesis, acupuncture, prokinetic, itopride

\section{1. Вступ}

Одним із найважчих проявів автономної нейропатії, який діагностують у 5-40 \% пацієнтів хворих на цукровий діабет (ЦД) вважають діабетичний гастропарез (ДГ). На жаль, відсутні фактичні статистичні дані про поширеність гастроінтестинальної форми вегетативної нейропатії шлунку, якому не приділяють достатньої уваги лікарі-клініцисти, що зумовлено важкістю ранньої діагностики у зв'язку із його перебігом під «масками» інших нозологічних одиниць, а також відмінностями у методології проведення досліджень моторно-евакуаторної функції (МЕФ) шлунку у хворих на ЦД. Уповільнення шлункового транзиту потенціює прогресування симптомів гастроезофагального рефлюксу, що сприяє порушенню випорожнення шлунку (гастропарез), прояви якого значно погіршують якість життя пацієнтів. Окрім дискомфорту у ділянці шлунку, блювоти фонтаном, зниження маси тіла, наявна варіабельність всмоктування глюкози, що зумовлює лабільний перебіг ЦД 3 частою зміною симптомів гіпо- і гіперглікемії. Багатогранність клінічних проявів спричинює труднощі у вчасному встановлені діагнозу, а відсутність своєчасного патогенетично обгрунтованого лікування також впливає на несприятливий прогноз. Незважаючи на значні успіхи у дослідженні етіопатогенетичних механізмів прогресування хронічних ускладнень ЦД, значного зниження їх поширеності досягнути не вдається $[1,2]$. На сьогодні, проблема вчасної діагностики, профілактики і лікування ДГ залишається надто актуальною. Тому одним із основних завдань сучасної медицини слід вважати вдосконалення діагностично-лікувальних алгоритмів для хворих на ЦД з ознаками брадигастрії шлунка внаслідок прогресування симптомів його парезу.

\section{2. Обгрунтування дослідження}

Більшість традиційних методів лікування характеризується використанням великої кількості медикаментів, які сприяють виникненню або загостренню виразкової хвороби шлунку, розвитку алергічних реакцій, метеоризму та інших ускладнень. 3 метою попередження хірургічного лікування важкого ступеня ДГ слід вчасно проводити корекцію терапії вже при діагностиці початкових проявів даного ускладнення із довготривалим застосуванням препаратів симптоматичної, патогенетичної терапій, а також використання індивідуалізованих лікуваль- них алгоритмів. Альтернативні принципи лікування: голковколювання, масаж вважають ефективними, безпечними i 3 мінімальною кількістю побічних ефектів. Протягом тисячоліть лікарі Східної медицини для лікування гастроінтестинальних захворювань широко використовують акупунктуру. Але тільки останні 20 років, китайські рефлексотерапевти проводять велику кількість наукових досліджень і розробляють схеми сеансів акупунктури для корекції симптомів ДГ [3-5]. Попри активне впровадження методів рефлексотерапії для корекції М-ЕФ шлунку у хворих на ЦД 1-го типу застосування викликає багато дискусій у зв'язку з відсутністю достатньої доказової бази: результати восьми міжнародних багатоцентрових досліджень із загальною кількістю обстежених 585 хворих на ЦД доведено ефективність сеансів акупунктури при уповільненні моторики шлунку, так як сприяють збудженню блукаючого нерва i гальмуванню симпатичних нервових закінчень. У літературі з'являються все більше даних, які доводять необхідність ширшого впровадження у щоденну медичну практику нових лікувальних комплексів [6-8].

На сьогодні залишаються остаточно не вирішеними питання індивідуалізованого підходу застосування симптоматичної терапії і не розроблено лікувального алгоритму корекції симптомів гастропарезу у хворих на ЦД 1-го типу.

\section{3. Мета дослідження}

Проведення оцінки ефективності сеансів акупунктури і прокінетику у комплексному лікуванні ДГ.

\section{4. Матеріали і методи}

Після підписання інформованої згоди проведено ретроспективний аналіз медичної документації і проспективний аналіз результатів терапії 66 хворих (30 чоловіків та 36 жінок, у віці від 22 до 42 років) на ЦД 1-го типу з ознаками порушення М-ЕФ шлунку, які перебували на лікуванні в ендокринологічному диспансерному та ендокринологічному відділеннях обласної клінічної лікарні м. Івано-Франківська. У діагностиці ЦД 1-го типу та оцінці ступеня компенсації вуглеводного обміну керувались національними стандартами (Наказ МО3 України № 1021 від 29.12.2014 р. «Уніфіковані клінічні протоколи первинної, вторинної (спеціалізованої) та третинної (високоспеціалізованої) медичної допомоги цукро- 
вий діабет 1 типу у молодих людей та дорослих») [2]. Ступінь важкості клінічного перебігу ДГ визначали за допомогою трьохвилинного анкетування пацієнтів «Gastroparesis Cardinal Symptom Index» (GCSI), яке дозволяє самостійно пацієнту провести оцінку вираженості симптомів. Ознаки оцінювали за 5-ти бальною шкалою, де 0 - відсутній, 1 - дуже легкий, 2 - легкий, 3 - середньої важкості, 4 - важкий, 5 - дуже важкий. Сума усіх балів від 1 до 11 свідчить про легкий ступінь важкості, тоді як від 12 до 22 балів - середньої важкості, важкий (23-33 бали), а дуже важкий - при значенні більше 34 бали.

3 метою оцінки М-ЕФ шлунку всім обстеженим запропоновано ${ }^{13} \mathrm{C}$-октаноєвий дихальний тест $\left({ }^{13} \mathrm{C}\right.$-ОДТ). Оцінку результатів проведено за часом напіввиведення (Т 1/2) вмісту шлунку у дванадцятипалу кишку: нормальний показник Т 1/2 складає 40 75 хвилин, прискорення моторики, якщо Т 1/2 менше 40 хвилин, легкого ступеня сповільнення моторики - 75-95 хвилин, від 96 до 115 хвилин - уповільнення середнього ступеня, більше 115 хвилин - уповільнення важкого ступеня.

За допомогою глюкозооксидантного методу на автоматичному аналізаторі АГКМ-01 «Кверті-Мед» (Україна) вимірювали глюкозу крові, рівень глікованого гемоглобіну $\left(\mathrm{HbA}_{1} \mathrm{C}\right)$ - методом високочутливої іонообмінної рідинної хроматографії.

Критеріями виключення пацієнтів із дослідження вважали наявність в анамнезі органічних уражень шлунково-кишкового каналу, вірусних гепатитів, жовчно-кам'яної хвороби, хворіб щитоподібної залози, а також застосування лікарських засобів, які впливають на моторику шлунку.

Ефективність лікування на клінічні прояви діабетичного гастропарезу (ДГ) оцінювали за трьома рівнями: «суттєве покращення», «покращення», «без змін».

Розрахунок індексу ефективності виконувався за формулою: (кіл-ть симптомів до лікування - кіл-ть симптомів після лікування) загальна кількість симптомів до лікування дано прокінетик ітоприд у добовій дозі 150,0 мг, тоді як пацієнти контрольної групи $(\mathrm{n}=20)$ отримували стандартний лікувальний комплекс без засобів симптоматичної терапії для нормалізації М-ЕФ шлунку. Між досліджуваними основної та контрольної груп не було суттєвих відмінностей за віковими, гендерними критеріями та базовою терапією. Пацієнтам першої групи складено рецептуру точок голковколювання, у якій використовували 1-2 точки для усунення симптомів порушення функції травлення, і одна точка - корекція вуглеводного обміну. Отже, 1-й день: Е36, J12, RP 6; 2-й день: RP 16, J13, E334; 3-й день: E34, J10, E37. 3 метою попередження щоденного використання одних і тих же точок, яке може привести до їх виснаження i значного зниження ефективності їх дії, вплив на точки чергували через кілька днів. Зокрема, на 4-й день повторювалося поєднання точок, які використовувалися у 1-й день, на 5-й - точки 2-го дня. Загалом лікувальний комплекс складався із 30 сеансів: кожен сеанс акупунктури тривав 40 хвилин, 5 днів на тиждень, щомісячно проводилося 10 сеансів, перерва між якими становила 14 днів. Друга група пацієнтів щоденно протягом трьох місяців отримувала прокінетик ітоприд у добовій дозі 150,0 мг (50,0 мг 3 рази/добу за 30 хвилин перед основним прийманням їжі), а хворим контрольної групи запропоновано стандартний курс лікування.

Для статистичної обробки матеріалу на всіх етапах дослідження були розроблені авторські комп'ютерні програми на основі Microsoft Excel (розрахунок відносних величин, їх похибок, t-тесту). Середні величини розраховувалися із використанням ліцензованих пакетів статистичного аналізу Microsoft Excel, зокрема програм описової статистики для показників з інтервальним типом шкали були представлені у вигляді середніх значень і стандартних відхилень. Якісні показники визначені у вигляді абсолютних частот і долей у групі у відсотках. Коефіцієнт кореляції визначався із використанням ліцензованих пакетів статистичного аналізу Statistica 7.0 за методом квадратів (метод Пірсона), значення $\mathrm{p}<0,05$ вважали вірогідним.

Для всіх обстежених дотримано заходів щодо слід вважати значення індексу $>75 \%$ - висока ефективність терапії, >25\% - ефективне лікування, $<25 \%$ - відсутній ефект.

Середня тривалість ЦД 1-го типу становить $18,6 \pm 2,7$ роки, і він супроводжується виникненням хронічних ускладнень: у 76,7 \% обстежених виявлено діабетичну полінейропатію, у 40,7 \% - діабетичну ретинопатію, а симптоми діабетичної нефропатії характерні для 19,9\% пацієнтів, що відповідає результатам інших досліджень $[1,2]$.

Для з'ясування ефективності сеансів акупунктури і прокінетика ітоприду хворих на Цд 1-го типу iз ознаками порушення моторики шлунку, нами обстежені стратифіковані на: першу групу $(\mathrm{n}=23)$ хворих, яким до лікувального комплексу проведено 30 сеансів акупунктури, а другій групі $(\mathrm{n}=23)$ - добезпеки здоров'я, прав пацієнта, людської гідності та морально-етичних норм відповідно до принципів Гельсінкської декларації прав людини, Конвенції Ради Європи про права людини і біомедицину та відповідних законів України.

\section{5. Результати дослідження}

При дослідженні М-ЕФ шлунку, стану компенсації вуглеводного обміну у хворих на ЦД 1-го типу виявлена вірогідна різниця у показниках, а запропоновані курси лікування завершили всі пацієнти, які відзначали хорошу їх переносимість. Інформація наукових джерел свідчить про наявність етіопатогенетичних зв'язків між станом компенсації ЦД і М-Е властивостями шлунку $[4,6,9]$. За результатами до- 
даткових обстежень нами встановлено наявність прямого середньої сили кореляційного зв'язку між сумою балів даних анкетування GSCI і результатами ${ }^{13} \mathrm{C}-\mathrm{OДT}$ $(\mathrm{r}=0,45 \pm 0,01, \mathrm{p}<0,05)$, а також сильний прямий зв'язок $(\mathrm{r}=0,76 \pm 0,02, \mathrm{p}<0,05)$ між станом компенсації вуглеводного обміну $\left(\mathrm{HbA}_{1} \mathrm{C}, \%\right)$ і ступенем уповільнення моторики шлунку за показниками ${ }^{13} \mathrm{C}-\mathrm{OДТ.}$

У 69,7 \% хворих на ЦД 1-го типу діагностовано суб'єктивні прояви симптомів уповільнення моторики шлунку, які були підтверджені заключенням ${ }^{13} \mathrm{C}-$ ОДТ- альтернативного методу інструментальної діагностики M-E функції, який на даний час прирівнюється до «золотого стандарту». В 21,7 \% (10 осіб) пацієнтів першої групи виявлено уповільнення часу напіввиведення вмісту шлунку у дванадцятипалу кишку легкого ступеня, а у 28,3 \% (13 пацієнтів) - середньої важкості, тоді як в обстежених другої групи брадигастрія легкого ступеня наявна у 26,1% (12 хворих), середнього ступеня - 23,9 \% (11 пацієнтів).

У хворих першої групи встановлено позитивну динаміку всіх суб'єктивних ознак ДГ, найбільш вираженими слід вважати зміни наступних: нудота - до лікування була у 18 (39,1 \%) хворих, після - тільки у 3 (6,5 \%); відчуття передчасного насичення їжею - до лікування 22 (47,8 \%) випадки, тоді як після лікування виявлено у 12 (26,1 \%); відчуття переповнення після прийому невеликої кількості їди - до лікування було у 20 (43,5 \%) пацієнтів, після - у 5 хворих (10,9\%); метеоризм (вздуття живота) відповідно до терапії у 14 (30,4 \%), а після тільки у 2 (4,3\%) хворих. А також позитивний ефект виявлено у досліджуваних другої групи: зменшилася частота випадків ну- доти 310 (21,7\%) до 6 (13,1\%); відчуття передчасного насичення їжею відповідно 22 (47,8 \%) до 14 (30,4 \%); переповнення після прийому невеликої кількості їди 323 (50\%) до 15 (32,6 \%); метеоризм - 17 (36,9\%) до 5 (10,9 \%) обстежених. На рис. 1. відображено аналіз результатів анкет-опитувальників (GCSI) першої і другої груп обстежених до та після запропонованих лікувальних алгоритмів.

Динаміка ознак симптомів ДГ та розрахунок ефективності лікувальних комплексів у залежності від груп хворих наглядно зображена графічно (рис. 2).

У пацієнтів першої групи спостерігається вірогідна позитивна динаміка проведеного курсу лікування на показники вуглеводного обміну, зокрема рівень глікованого гемоглобіну знизився на 26,3 \% $(\mathrm{p}<0,05)$, а у хворих другої і контрольної груп виявлено лише тенденцію до зниження відповідно на $21,3 \%(p>0,05)$ і на 9,1 \% (p>0,05). Результати ${ }^{13} \mathrm{C}-\mathrm{OДТ}$ підтверджують високу ефективність лікувального комплексу із використанням сеансів акупунктури у досліджуваних першої групи у динаміці відновлення М-ЕФ шлунку на $14,6 \%(\mathrm{p}<0,05)$, тоді як у хворих другої групи - тільки на $6,5 \%$ (p<0,05), а у пацієнтів контрольної групи виявлено незначну тенденцію до нормалізації даного показника $(\Delta-3,7, \mathrm{p}>0,05)$. Дані зміни можна розцінити, як наявність патогенетично обгрунтованих зв'язків між станом компенсації вуглеводного обміну і функціональними властивостями шлунку. Інші характеристики критеріїв ефективності лікування досліджуваних груп пацієнтів із врахуванням стану вуглеводного обміну у хворих на ЦД 1-го типу відображені у табл. 1.

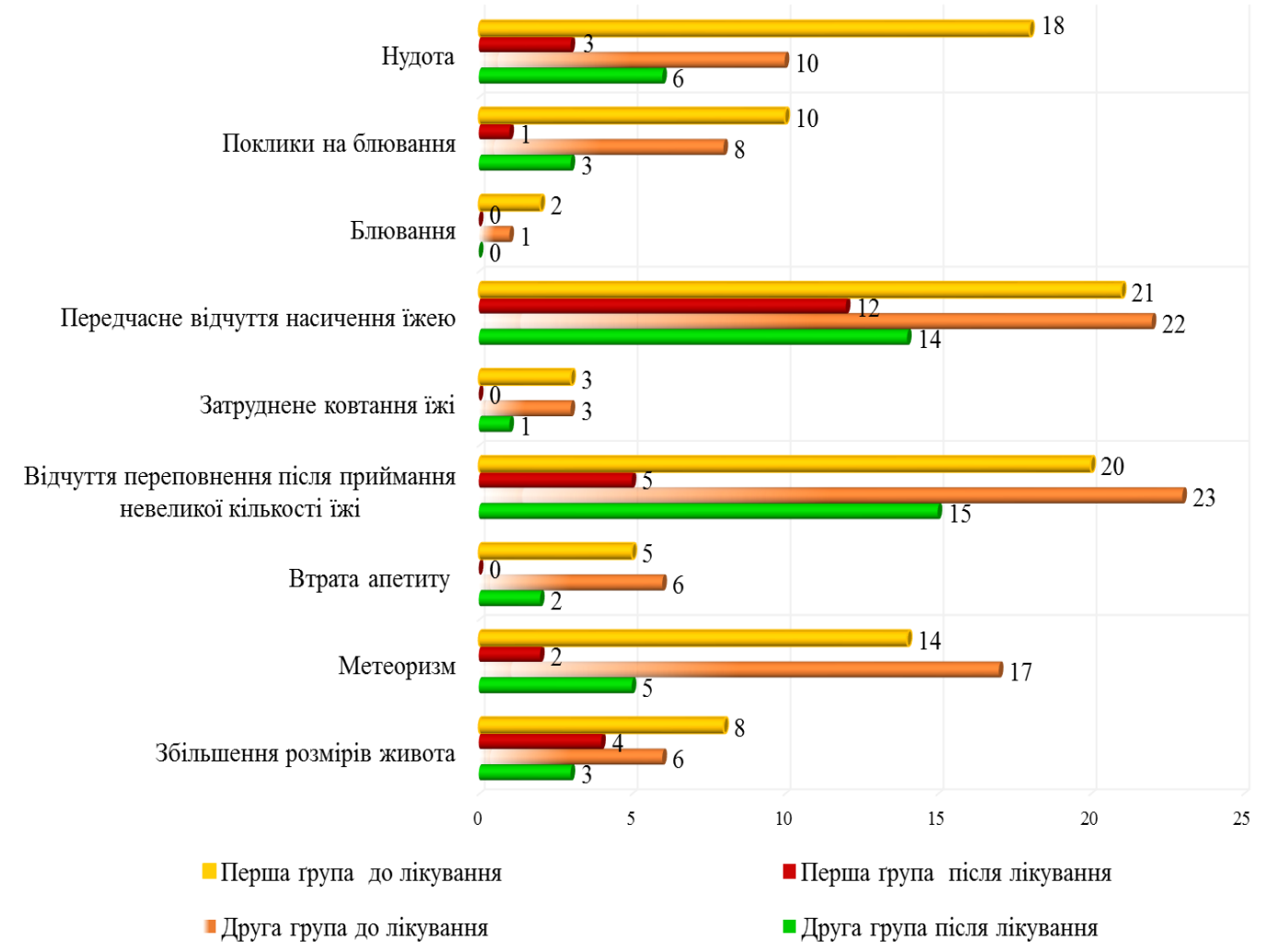

Рис. 1. Динаміка частоти виникнення симптомів ДГ (кількість обстежених) за результатами анкетування GCSI, бали 


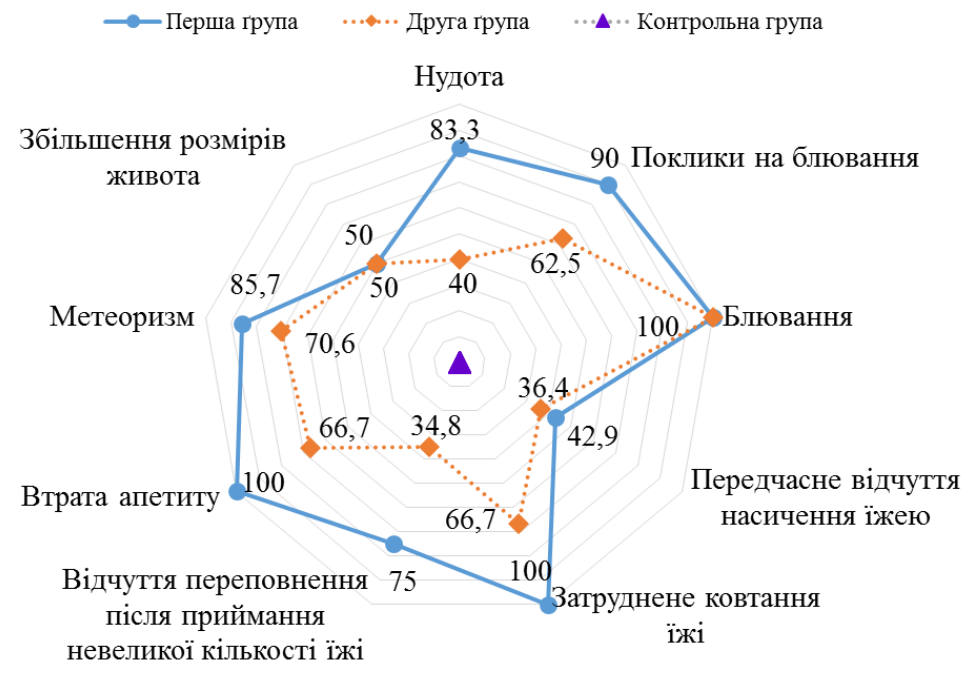

Рис. 2. Індекс ефективності ( \%) за даними опитувальника GCSI проведеного курсу лікування у пацієнтів хворих на ЦД 1-го типу з ознаками порушення моторики шлунку

Таблиця 1

Зміна показників вуглеводного обміну і М-ЕФ шлунку у досліджуваних після лікування

\begin{tabular}{|c|c|c|c|c|c|c|c|c|c|}
\hline \multirow{4}{*}{ Показники } & \multicolumn{9}{|c|}{ Групи обстежених } \\
\hline & \multicolumn{3}{|c|}{ Перша, $\mathrm{n}=23$} & \multicolumn{3}{|c|}{ Друга, $\mathrm{n}=23$} & \multicolumn{3}{|c|}{ Контрольна, $\mathrm{n}=20$} \\
\hline & до & після & \multirow{2}{*}{$\Delta, \%$} & до & після & \multirow{2}{*}{$\Delta, \%$} & до & після & \multirow{2}{*}{$\Delta, \%$} \\
\hline & \multicolumn{2}{|c|}{ лікування } & & \multicolumn{2}{|c|}{ лікування } & & \multicolumn{2}{|c|}{ лікування } & \\
\hline \multicolumn{10}{|c|}{ Вуглеводний обмін } \\
\hline $\begin{array}{c}\text { Глікований гемоглобін } \\
(\mathrm{HbA}, \mathrm{C}), \% \\
\end{array}$ & $9,7 \pm 1,0$ & $7,2 \pm 0,7^{\infty}$ & $-26,3$ & $9,8 \pm 1,5$ & $7,7 \pm 0,5$ & $-21,3$ & $8,6 \pm 1,3$ & $7,9 \pm 0,3$ & $-9,1$ \\
\hline $\begin{array}{c}\text { Прандіальна глікемія, } \\
\text { ммоль/л }\end{array}$ & $9,2 \pm 0,5$ & $8,2 \pm 0,1^{\infty}$ & $-10,8$ & $9,8 \pm 0,6$ & $8,1 \pm 0,4$ & $-16,9$ & $8,3 \pm 0,8$ & $7,9 \pm 1,4$ & $-4,7$ \\
\hline $\begin{array}{c}\text { Постпрандіальна глікемія, } \\
\text { ммоль/л }\end{array}$ & $11,2 \pm 1,0$ & $8,6 \pm 0,7^{\infty}$ & $-23,3$ & $10,9 \pm 1,1$ & $9,4 \pm 1,1$ & $-13,4$ & $10,7 \pm 1,2$ & $9,9 \pm 0,6$ & $-6,9$ \\
\hline \multicolumn{10}{|c|}{ Інструментальна оцінка М-ЕФ шлунку } \\
\hline${ }^{13} \mathrm{C}-\mathrm{ОДТ,Т} \mathrm{1/2,} \mathrm{хв}$ & $98,6 \pm 4,2$ & $84,2 \pm 3,2 *$ & $-14,6$ & $97,5 \pm 2,2$ & $91,2 \pm 2,1^{\infty}$ & $-6,5$ & $56,5 \pm 7,2$ & $54,4 \pm 6,4$ & $-3,7$ \\
\hline
\end{tabular}

\section{6. Обговорення результатів дослідження}

Результати проведених нами досліджень показали, що відновлення М-Е функції шлунку, залежить від ряду чинників, зокрема стану компенсації вуглеводного обміну та індивідуалізованого підбору засобів симптоматичного лікування із можливим використанням сеансів акупунктури чи прокінетичних засобів.

Ефективність застосування сеансів голковколювання в якості покращення М-Е функції шлунку доведено у ряді наукових робіт [3, 9, 10], які вказують на позитивну динаміку перебігу Цд з попередженням його лабільного перебігу і зниження ризику прогресування інших хронічних ускладнень [11].

Встановлено, що застосування сеансів акупунктури тривалістю 40 хвилин 5 днів на тиждень протягом двох тижнів, 3 перервою 14 днів (загалом 3 курси) в якості симптоматичного лікування, на відміну від курсового трьохмісячного прийому прокінетику ітоприд у дозуванні 150 мг/добу за даними анкетування GSCI володіє високою ефективністю (75,0 \%) у 26,1-30,4 \% випадків. А також досягнуто вираженої позитивної динаміки показників глікемічного профілю у хворих першої групи: зниження рівня показників поспрандіальної глікемії на 23,3% (p<0,001), тоді як у хворих другої групи тільки на $13,4 \%$ (p $<0,05)$, а у контрольної групи - 6,9% (p>0,05). Відповідно враховуючи наявність кореляційної залежності між показниками вуглеводного контролю і станом М-ЕФ шлунку у хворих на ЦД 1-го типу, патогенетично обгрунтовано відновлення моторики шлунку, що і підтверджено результатами ${ }^{13} \mathrm{C}-\mathrm{OДТ} \mathrm{у} \mathrm{динаміці} \mathrm{у} \mathrm{першої}(\Delta-14,6 \%)$ і другої $(\Delta-6,5 \%)$ групи обстежуваних.

Аналіз отриманих нами даних, свідчать, що сеанси акупунктури є швидкодіючими, ефективними i безпечними для пацієнтів хворих на ЦД 1-го типу та ознаками уповільнення М-ЕФ шлунку. Крім того, слід вказати на низку переваг даного лікувального комплексу, що дозволяє ефективно запобігти прогресування симптомів дизмоторики шлунку, економічно вигідніший від прийому великої кількості препаратів медикаментозної терапії, а також відсутній токсичний вплив хімічних середників $[5,7]$.

\section{7. Висновки}

Для ранньої діагностики ДГ усім хворим із лабільним перебігом ЦД рекомендовано проводити обстеження M-ЕФ шлунку (анкетування GCSI, ${ }^{13} \mathrm{C}-\mathrm{OДT}$ ). 
У 69,7 \% хворих на ЦД 1-го типу із поганим глікемічним контролем за результатами анкет-опитувальників (GCSI) й ${ }^{13} \mathrm{C}-$ ОДТ виявлено уповільнення М-ЕФ шлунку легкого і середнього ступеня важкості, що характерно для початкових проявів гастропарезу.

Доведена достовірна ефективність застосування сеансів акупунктури у комплексному лікуванні хворих на ЦД 1-го типу із ознаками брадигастрії, так як спостерігається виражена позитивна динаміки показників вуглеводного обміну і М-ЕФ шлунку.

\section{Література}

1. Cefalu, W. T. The Diabetes Control and Complications Trial Epidemiology of Diabetes Interventions and Complications Study at 30 Years: The "Gift" That Keeps on Giving! [Text] / W. T. Cefalu, R. E. Ratner// Diabetes Care. - 2013. - Vol. 37, Issue 1. - P. 5-7. doi: 10.2337/dc13-2369

2. Цукровий діабет 1 типу у молодих людей і дорослих адаптована клінічна настанова, заснована на доказах [Електронний ресурс]. - Наказ Міністерства охорони здоров’я України, 2014. - № 1021. - Режим доступу: http:// www.dec.gov.ua/mtd/_cd1_dor.html

3. Ge, J. Y. Acupuncture for treatment of 30 cases ofdiabetic gastroparesis [Text] / J. Y. Ge, S. L. Zheng, F. J. Song, J. Jiangxi // Tradit. Chin. Med. - 2010. - Vol. 41, Issue 2. - P. 55-56.

4. Hu, Z. H. Research for Optimizing the Acupuncture-moxibustion Treatment Protocol for Diabetic Gastroparesis [Text] / Z. H. Hu, Y. Wang, J. Y. Huang et. al. // Shanghai Journal of Acupuncture and Moxibustion. - 2014. - Vol. 12. - P. 1094-1096.

5. Camilleri, M. Clinicalguideline: management of gastroparesis [Text] / M. Camilleri, H. P. Parkman, M. A. Shafi, T. L. Abell, L. Gerson // The American Journal of Gastroenterology. -2012. - Vol. 108, Issue 1.-P. 18-37. doi: 10.1038/ajg.2012.373

6. Aljarallah, B. Management of diabetic gastroparesis [Text] / B. Aljarallah // Saudi Journal of Gastroenterology. 2011. - Vol. 17, Issue 2. - P. 97. doi: 10.4103/1319-3767.77237

7. Liu, H. Treatment of Diabetic Gastroparesis by Complementary and Alternative Medicines[Text] / H. Liu, B. Yu, M. Zhang, K. Liu, F.-C. Wang, X.-Y. Gao // Medicines. - 2015. Vol. 2, Issue 3. - P. 212-219. doi: 10.3390/medicines2030212

8. Lee, L. A. Complementary and Alternative Medicine for Gastroparesis [Text] / L. A. Lee, J. Chen, J. Yin // Gastroenterology Clinics of North America. - 2015. - Vol. 44, Issue 1. P. 137-150. doi: 10.1016/j.gtc.2014.11.011

9. Park, J. Acupuncture for ankle sprain: systematic review and meta-analysis [Text] / J. Park, S. Hahn, J.-Y. Park, H.-J. Park, H. Lee // BMC Complementary and Alternative Medicine. - 2013. - Vol. 13, Issue 1. doi: 10.1186/1472-6882-13-55

10. Yang, M. Meta-analysis of acupuncture for relieving non-organic dyspeptic symptoms suggestive of diabetic gastroparesis [Text] / M. Yang, X. Li, S. Liu, Z. Li, M. Xue, D. Gao et. al. // BMC Complementary and Alternative Medicine.2013. - Vol. 13, Issue 1. doi: 10.1186/1472-6882-13-311
11. Catherine, L. M. Neuropathy and Related Findings in the Diabetes Control and Complications Trial/Epidemiology of Diabetes Interventions and Complications Study [Text] / C. L. Martin, J. W. Albers, R. Pop-Busui // Diabetes Care. 2013. - Vol. 37, Issue 1. - P. 31-38. doi: 10.2337/dc13-2114

\section{References}

1. Cefalu, W. T., Ratner, R. E. (2013). The Diabetes Control and Complications Trial/Epidemiology of Diabetes Interventions and Complications Study at 30 Years: The "Gift" That Keeps on Giving! Diabetes Care, 37 (1), 5-7. doi: $10.2337 / \mathrm{dc} 13-2369$

2. Unified clinical protocol of primary, emergency, secondary (specialized) and tertiary (highly) medical care "Type 1 diabetes in young people and adults" (2014). The order of $\mathrm{MoH}$ of Ukraine, 1021. Available at: http://www.dec.gov.ua/mtd/ cd1_dor.html

3. Ge, J. Y., Zheng, S. L., Song, F. J., Jiangxi, J. (2010). Acupuncture for treatment of 30 cases ofdiabetic gastroparesis. Tradit. Chin. Med., 41 (2), 55-56.

4. Hu, Z. H., Wang, Y., Huang, J. Y. et. al. (2014). Research for Optimizing the Acupuncture-moxibustion Treatment Protocol for Diabetic Gastroparesis. Shanghai Journal of Acupuncture and Moxibustion, 12, 1094-1096.

5. Camilleri, M., Parkman, H. P., Shafi, M. A., Abell, T. L., Gerson, L. (2012). Clinical Guideline: Management of Gastroparesis. The American Journal of Gastroenterology, 108 (1), 18-37. doi: 10.1038/ajg.2012.373

6. Aljarallah, B. (2011). Management of diabetic gastroparesis. Saudi Journal of Gastroenterology, 17 (2), 97. doi: 10.4103/1319-3767.77237

7. Liu, H., Yu, B., Zhang, M., Liu, K., Wang, F.-C., Gao, X.-Y. (2015). Treatment of Diabetic Gastroparesis by Complementary and Alternative Medicines. Medicines, 2 (3), 212 219. doi: 10.3390/medicines2030212

8. Lee, L. A., Chen, J., Yin, J. (2015). Complementary and Alternative Medicine for Gastroparesis. Gastroenterology Clinics of North America, 44 (1), 137-150. doi: 10.1016/ j.gtc.2014.11.011

9. Park, J., Hahn, S., Park, J.-Y., Park, H.-J., Lee, H. (2013). Acupuncture for ankle sprain: systematic review and meta-analysis. BMC Complementary and Alternative Medicine, 13 (1). doi: 10.1186/1472-6882-13-55

10. Yang, M., Li, X., Liu, S., Li, Z., Xue, M., Gao, D. et. al. (2013). Meta-analysis of acupuncture for relieving non-organic dyspeptic symptoms suggestive of diabetic gastroparesis. BMC Complementary and Alternative Medicine, 13 (1). doi: 10.1186/1472-6882-13-311

11. Martin, C. L., Albers, J. W., Pop-Busui, R. (2013). Neuropathy and Related Findings in the Diabetes Control and Complications Trial/Epidemiology of Diabetes Interventions and Complications Study. Diabetes Care, 37 (1), 31-38. doi: $10.2337 / \mathrm{dc} 13-2114$

Рекомендовано до публікаиії д-р мед. наук, професор Маньковський Б. М. Дата надходження рукопису 11.05.2016

Костіцька Ірина Олександрівна, кандидат медичних наук, доцент, кафедра ендокринології, ІваноФранківський національний медичний університет, вул. Галицька, 99/1, м. Івано-Франківськ, Україна, 76019 E-mail: irynakostitska@ukr.net 